УДК: 377.3:687]:[37.091.279.7:37.091.12-057.86]

DOI:

Галина Однорог, аспарінтка Інституту професійно-технічної освіти Національної академї педагогічних наук України

\title{
ЕКСПЕРТНЕ ОЦНЮВАННЯ КЛЮЧОВИХ КОМПЕТЕНТНОСТЕЙ ДЛЯ ПРОФЕСІЙ ШВЕЙНОГО ПРОФІЛЮ
}

Стаття присвячена висвітленню результатів експертного оцінювання ключових компетентностей майбутніх кваліфікованих робітників швейного профілю. Здійснено теоретичний аналіз законодавчих документів і нормативно-правових актів з проблеми дослідження. Виконано статистичні розрахунки з метою визначення ступеня узгодженості думок експертів та достовірності даних. Представлено перелік найбільи затребуваних здібностей для майбутніх кравців $і$ закрійників.

Ключові слова: ключові компетентності; експертне оцінювання; кваліфікований робітник; кравець; закрійник; професійна-технічна освіта.

Рис. 2. Табл. 10. Лім. 10.

Halyna Odnoroh, Postgraduate Student of the Institute for Vocational Education of the National Academy of Pedagogical Sciences of Ukraine

\section{EXPERT EVALUATION OF KEY COMPETENCIES FOR SEWING PROFESSIONS}

Purpose: based on expert assessment of the content of key competencies necessary for the formation of professionalism of future skilled workers in the sewing profile, to determine a professionally oriented set of personality qualities for their further development by means of interactive technologies.

Methods: the theoretical analysis of domestic educational legislation to form a general list of key competencies; comparison and generalization - to highlight in the content of the described key competencies the most in demand qualities and abilities of specialists in the labor market in the garment industry; empirical (expert evaluation) - for the formation of a professionally oriented set of qualities and abilities of specialists in the garment industry, the development of which is sensitive to the use of interactive technologies; mathematical and statistical (concordance coefficient of opinion agreement, Pearson's agreement criterion, Microsoft Excel program, Google Form application) - for the formation and conduct of expert evaluation, processing of the obtained data.

Results: on the basis of the analysis of the domestic educational legislation the general list of key competences of experts of a sewing profile is formed; based on the results of the expert assessment of their content, the most demanded qualities and abilities of future skilled workers by the labor market in the garment industry are compiled. the development of which is sensitive to the use of interactive technologies; the definition of the concept "key competencies of future skilled sewing workers" is formulated.

Conclusions: it was found that the key competencies of future skilled workers in the sewing profile is a specially structured professionally oriented set of qualities and abilities of the individual needed to achieve professional success, to increase competitiveness, to form professional mobility and adaptiveness in the labor market for tailors and cutters: ability to communicate orally and in writing; ability to apply mathematical knowledge and methods to solve problems in everyday life; responsibility for the consequences of human activity; ability to respond to change and overcome difficulties; understanding the importance of nature conservation to ensure sustainable development of society; ability to confidently, critically and responsibly use digital technologies; ability to find opportunities for learning and self-development; ability to show tolerance, be able to cooperate constructively, overcome stress and act in conflict situations; the desire to develop and express their own ideas, feelings through culture and art; willingness to take responsibility for decisions made; ability to work in a team to plan and implement projects.

Keywords: key competencies; expert evaluation; skilled worker; tailor; cutter; vocational education.

П остановка проблеми в загальному вигляді. Україна продовжує рухатися у напрямі змін, спрямованих на розвиток економіки та промисловості. Це впливає i на вимоги ринку праці до рівня кваліфікації робітничих кадрів. Тому, особливого значення набуває оновлення змісту професійної освіти. Реформа професійної освіти спрямована на випереджувальний розвиток системи професійної освіти і навчання; на задоволення потреб “особистості, суспільства і держави" у сфері професійної освіти, враховуючи світовий досвід та потреби вітчизняного ринку праці; “на забезпечення рівного доступу до якісної професійної освіти і навчання впродовж життя" [5]. 3 метою наближення національної професійної освіти до високих показників якості світової професійної освіти під час визначення переліку та 


\section{ЕКСПЕРТНЕ ОЩНЮВАННЯ КЛЮЧОВИХКОМПЕТЕНТНОСТЕЙ ДЛЯ ПРОФЕСІЙ ШВЕЙНОГОПРОФІЛЮ}

змісту ключових компетентностей майбутніх кваліфікованих робітників, необхідно також спиратися на досвід зарубіжних країн $[6,65]$.

У змісті “Методики розроблення професійних стандартів" [7], затверджених 22. 01. 2018 р., відсутній термін “ключові компетентності”, але використовується поняття “загальні компетентності”, що визначається як “універсальні компетентності (соціальні, комунікативні, особистісні, екологічні, етичні тощо), що не залежать від предметної сфери, є важливими для успішної професійної та соціальної діяльності особи”. Вони формуються для кожної професії залежно від специфіки. У даній Методиці наведений приклад загальних компетентностей, а саме: уважність; розвинена зорова та слухова пам'ять; емоційна стійкість; стресостійкість; відповідальність; розвинена орієнтація в просторі; здатність до адаптації; здатність діяти в нестандартних ситуаціях; здатність працювати в команді; запобігання конфліктним ситуаціям; володіння професійною термінологією; дотримуватись професійної етики; здатність прогнозувати результати діяльності тощо.

Вивчаючи ДСПТО для професій "Швачка" (код 7436), “Кравець” (код 7433), “Закрійник” (код 7435) [4, 3; 3, 3-4; 2, 3], розроблені у 2016 р., відзначаємо, що за даними стандартами компетентності поділяються на професійні (професійні базові та професійні профільні) і загальні, (формуються у процесі загальнопрофесійної, професійно-теоретичної і професійно-практичної підготовки). Для даних професій загальні компетентності є однаковими і визначаються у стандартах наступним чином: оперативність у прийнятті правильних рішень у позаштатних ситуаціях під час роботи; здатність відповідально ставитися до професійної діяльності; знання професійної лексики та термінології; здатність діяти в нестандартних ситуаціях; здатність працювати в команді; дотримання професійної етики; запобігання конфліктних ситуацій $[3,13 ; 2,14]$.

Варто зауважити, що в переліку даних компетентностей не зазначені знання, уміння й навички, що охоплюють всі ключові компетентності, передбачені Законом України “Про освіту”. Уміння оперативно ухвалювати правильні рішення у позаштатних робочих ситуаціях та здатність діяти в нестандартних ситуаціях - вважаємо синонімічними, оскільки позаштатні ситуації передбачають наявність уміння фахівця за обмежений час вирішувати нестандартні задачі.

Затверджені “Методичні рекомендації щодо розроблення стандартів професійної (професійно- технічної) освіти за компетентнісним підходом" (від 17 лютого 2021 року) [8] містять перелік ключових компетентностей за професією: грамотність; мовна компетентність; математична компетентність та компетентність у науці, технологіях та інженерії; цифрова компетентність; особистісна, соціальна й навчальна компетентність; громадянська компетентність; підприємницька компетентність; усвідомлення та вираження культури; екологічна та енергоефективна компетентність. У даному документі зазначено, що ключові компетентності “ $€$ наскрізними $і$ набуваються здобувачами на всіх рівнях освіти". Документ орієнтований на оновлені ключові компетентності, визначені Рамковою програмою ЄС. У даних Методичних рекомендаціях зазначається також, що перелік ключових компетентностей формується 3 урахуванням “їх значущості для конкретної професії чи кваліфікації відповідно до професійного стандарту / кваліфікаційної характеристики".

Виходячи 3 вищевикладеного, можна узагальнити, що:

1. Дефініції “ключові компетентності” та “"загальні компетентності” у законодавчо-нормативних документах вживаються у синонімічних значеннях;

2. Існуючий перелік ключових компетентностей майбутніх фахівців швейної промисловості $€$ неповним, оскільки не відображає всі напрями діяльності майбутніх фахівців швейного профілю та враховує не всі ключові компетентності, визначені законодавством.

Аналіз останніх досліджень і публікацій. Питанню формування та розвитку ключових компетентностей присвячені роботи вітчизняних і зарубіжних науковців, зокрема: В. Байденко, Е. Зеєра, І. Зимньої, О. Овчарук, Н. Бібік, В. Ягупов, В. Радкевич, Дж. Равен, А. Хуторський та ін. Серед дисертаційних досліджень, спрямованих на вирішення питань розвитку ключових компетентностей, виділяємо ті, що присвячені формуванню ключових компетентностей у процесі професійної підготовки майбутніх фахівців ресторанного сервісу (С. Кравець), вивченню значення ключових компетентностей у створенні професійних стандартів (Л. Короткова), створенню психологічних умов формування професійної компетентності учнів ЗП(ПТ)О сфери обслуговування (І. Матійків) та ін.

Мета статті - на основі експертного оцінювання змісту ключових компетентностей, необхідних для становлення професіоналізму майбутніх кваліфікованих робітників швейного 


\section{ЕКСПЕРТНЕ ОЩНЮВАННЯ КЛЮЧОВИХКОМПЕТЕНТНОСТЕЙ ДЛЯ ПРОФЕСІЙ ШВЕЙНОГО ПРОФІЛЮ}

профілю, визначити професійно орієнтований комплекс якостей особистості для подальшого їнього розвитку засобами інтерактивних технологій.

Виклад основного матеріалу. Для визначення переліку затребуваних сучасним ринком праці (значущих) особистісних якостей i здібностей кравців і закрійників було проведено експертне оцінювання вагомості якостей і здібностей на основі переліку ключових компетентностей, визначених Законом України "Про освіту".

Для експертизи було залучено три групи експертів по п'ять осіб із наукової, педагогічної та виробничої сфер (рис. 1, 2), що дало змогу врахувати різні точки зору.

Для визначення вагомості здібностей експертам пропонувалося заповнити форму (https:/
/forms.gle/Vf6eQNArWL8PhoMGA) та проранжувати складові змісту (якості, здібності) кожної 311 ключових компетентностей, визначених Законом України "Про освіту", орієнтуючись на їх суттєвість для професій “Кравець” і “Закрійник”. Такі ключові компетентності як “вільне володіння державною мовою” та “здатність спілкуватися рідною та іноземною мовами” ми об'єднали в одну “мовну” компетентність, оскільки зміст даних компетентностей тісно переплітається і повторюється.

Результати ранжування експертами затребуваних здібностей подано у таблицях 1-10 та результатах гугл-форми (https://cutt.ly/IQZLBPD).

3 метою перевірки гіпотези про наявність узгодження думок для кожної групи здібностей розраховано множинний коефіцієнт конкордації, за формулою 1. Даний коефіцієнт розраховується для

\section{Сфера діяльності \\ 15 відповідей}

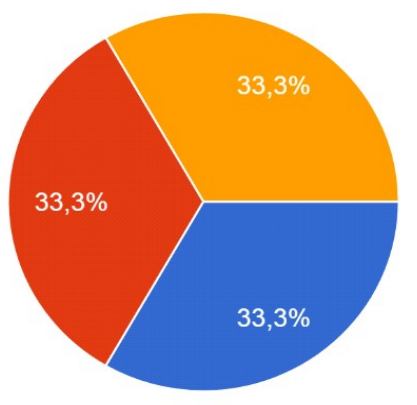

наукова

педагогічна

виробнича

Рис.1. Кількісний показник сфери діяльності експертів

Стаж роботи

15 відповідей

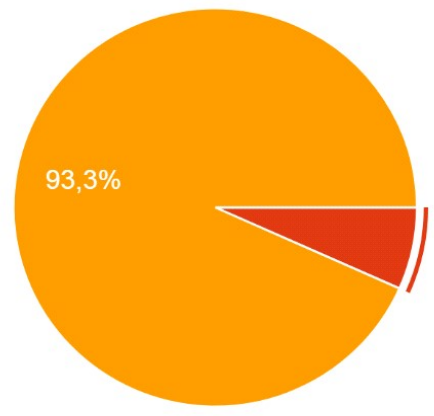

більше 10 років

Рис. 2. Кількісний показник експертів за стажем роботи 


\section{ЕКСПЕРТНЕ ОЩНЮВАННЯ КЛЮЧОВИХКОМПЕТЕНТНОСТЕЙ ДЛЯ ПРОФЕСІЙ ШВЕЙНОГО ПРОФІЛЮ}

вимірювання ступеня узгодження двох або декількох рядів ранжованих значень змінних [9, 124]. Значення цього коефіцієнту повинно знаходитися в діапазоні $0 \leq \mathrm{W} \leq 1$, чим більше він наближений до 1, тим вищою $є$ узгодженість думок $[10,20]$.

$$
W=\frac{12 \times S}{m^{2}\left(n^{3}-n\right)},
$$

де $\mathrm{W}$ - коефіцієнт конкордації;

m - кількість експертів;

n - кількість педагогічних умов;

$$
S=\sum_{j=1}^{n}\left(\sum_{j=1}^{m} R i j\right)^{2}-\frac{\left(\sum_{j=1}^{n} \sum_{j=1}^{m} \boldsymbol{R}_{i j}\right)^{2}}{n}, 2
$$

$\mathrm{S}$ - сума квадратів різниць рангів, яка розраховується за формулами 2 .

Для перевірки значущості коефіцієнта конкордації обчислюємо значення критичної точки за допомогою критерію Пірсона $x^{2}$, за формулою 3. За рівнем значущості $\alpha(0,05)$ i числом ступенів свободи $f=n-1$ в таблицях Пірсона знаходимо критичне значення $x_{\text {кр }}^{2}$. Якщо $x_{\phi}^{2}>x_{\text {кр }}^{2}$, то коефіцієнту конкордації

$$
x_{\phi}^{2}=m(n-1) W, \quad 3
$$

можна довіряти й отримані на його основі висновки є достовірними.

За результатами ранжування мовної компетентності (табл. 1) визначено затребуваною для кравців та закрійників “здатність здійснювати комунікацію в усній та письмовій формі”.

$x_{\phi}^{2}=33,2>7,8$, отже з ймовірністю $95 \%$ можемо стверджувати, що значення коефіцієнта конкордації $є$ невипадковим.

У випадку, коли при ранжуванні експерт не може надати перевагу одному з двох і більше об'єктів, необхідно присвоїти стандартизовані ранги $[1,89]$. Розрахунок стандартизованого рангу виконується наступним чином: якщо експерт присвоїв два 1-их ранги, то вони займають 1 і 2 місце в загальній системі ранжування, тому кожному 3 них присвоюється ранг 1,5, розрахований наступним чином: $(1+2) \div 2=1,5$. Якщо експерт присвоїв три 2-их ранги, то вони займають 2, 3 і 4 місце в загальній системі ранжування, тому кожному 3 них присвоюється ранг 3 , розрахований наступним чином: $(2+3+4)$ $\div 3=3$. Сума рангів $\sum_{j=1}^{n} R_{i j}$ по кожному експерту повинна бути однакова, оскільки $є$ контрольною, за нею перевіряється правильність уточнення рангів. Сума рангів за експертами та здібностями повинна співпадати, що також $\epsilon$ контрольною величиною.

Таблиця 1.

Експертне оцінювання здібностей мовної компетентності

\begin{tabular}{|c|c|c|c|c|c|c|c|c|c|c|c|c|c|c|c|c|c|}
\hline \multirow[t]{2}{*}{ Здатності (n) } & \multicolumn{15}{|c|}{ Експерти (m) } & \multirow{2}{*}{$\sum_{j=1}^{m} R_{i j}$} & \multirow[t]{2}{*}{ Місце } \\
\hline & 1 & 2 & 3 & 4 & 5 & 6 & 7 & 8 & 9 & 10 & 11 & 12 & 13 & 14 & 15 & & \\
\hline $\begin{array}{l}\text { здатність } \\
\text { здійснювати } \\
\text { комунікацію в усній } \\
\text { та письмовій }\end{array}$ & 1 & 1,5 & 1,5 & 1 & 1 & 1,5 & 2 & 1 & 1 & 1,5 & 1 & 1 & 1 & 1,5 & 1 & 18,5 & 1 \\
\hline $\begin{array}{l}\text { здатність здобувати } \\
\text { та опрацьовувати } \\
\text { iнформацію з різних } \\
\text { джерел }\end{array}$ & 2 & 1,5 & 1,5 & 2 & 2 & 1,5 & 4 & 2 & 2 & 1,5 & 2 & 2 & 2 & 1,5 & 2 & 29,5 & 2 \\
\hline $\begin{array}{l}\text { здатність } \\
\text { використовувати } \\
\text { мовні засоби для } \\
\text { досягнення } \\
\text { особистих і } \\
\text { суспільних цілей }\end{array}$ & 4 & 3,5 & 3,5 & 4 & 4 & 3,5 & 2 & 4 & 4 & 3,5 & 4 & 4 & 4 & 3,5 & 4 & 55,5 & 4 \\
\hline $\begin{array}{l}\text { здатність виражати } \\
\text { ідеї, почуття, } \\
\text { пояснювати та } \\
\text { обгрунтовувати } \\
\text { факти, свої погляди } \\
\text { та переконання }\end{array}$ & 3 & 3,5 & 3,5 & 3 & 3 & 3,5 & 2 & 3 & 3 & 3,5 & 3 & 3 & 3 & 3,5 & 3 & 46,5 & 3 \\
\hline$\sum_{i=1}^{n} R_{i j}$ & 10 & 10 & 10 & 10 & 10 & 10 & 10 & 10 & 10 & 10 & 10 & 10 & 10 & 10 & 10 & 150 & \\
\hline $\mathrm{S}$ & & & & & & & & & & & & & & & & & 830 \\
\hline $\mathbf{W}$ & & & & & & & & & & & & & & & & & 0,74 \\
\hline
\end{tabular}

(“вільне володіння державною мовою”, “здатність спілкуватися рідною та іноземними мовами") 
Таблиця 2.

Експертне оцінювання здібностей математичної компетентності

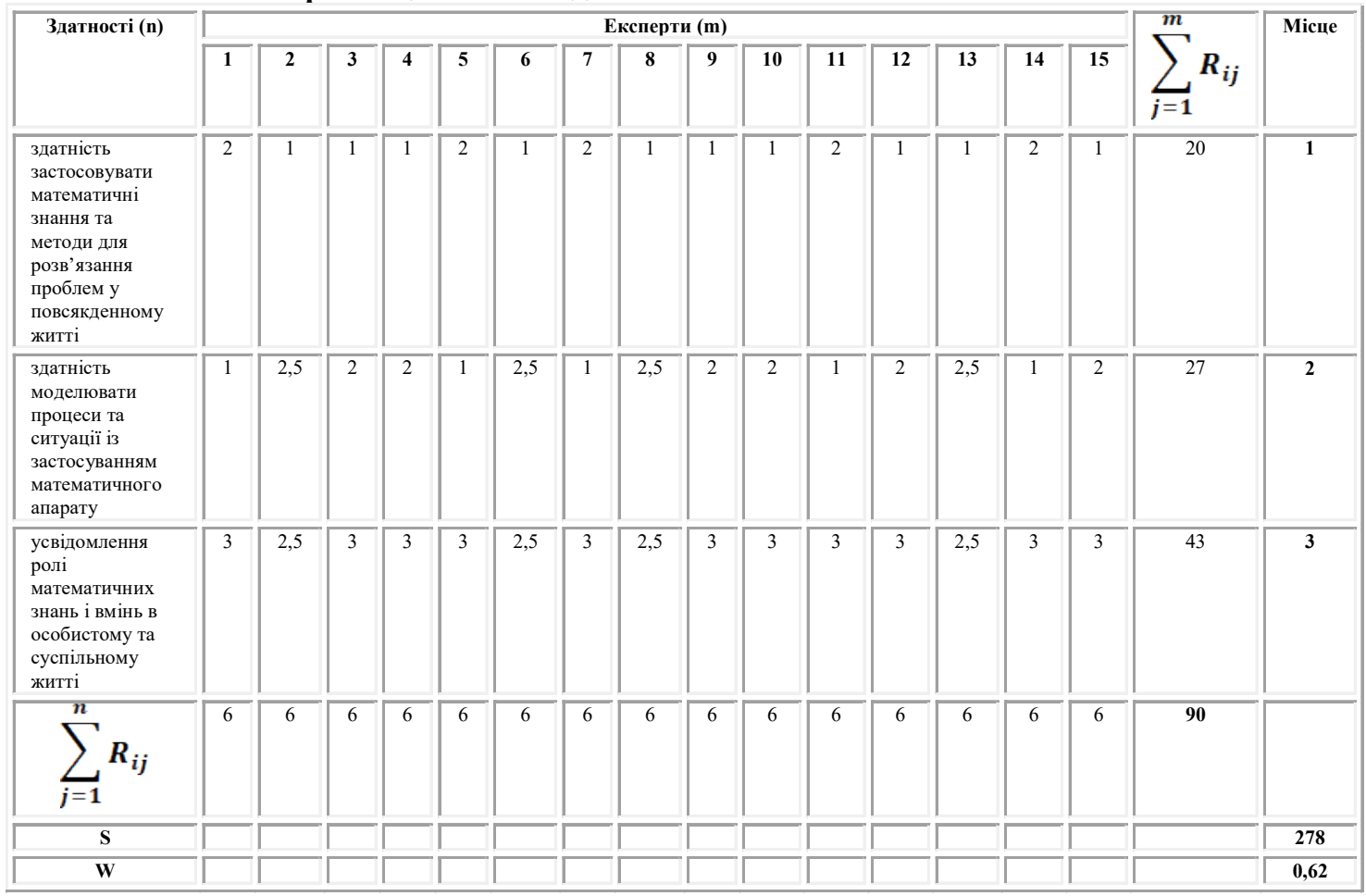

Експертне оцінювання здібностей компетентності

Таблиця 3.

в галузі природничих наук, техніки і технологій

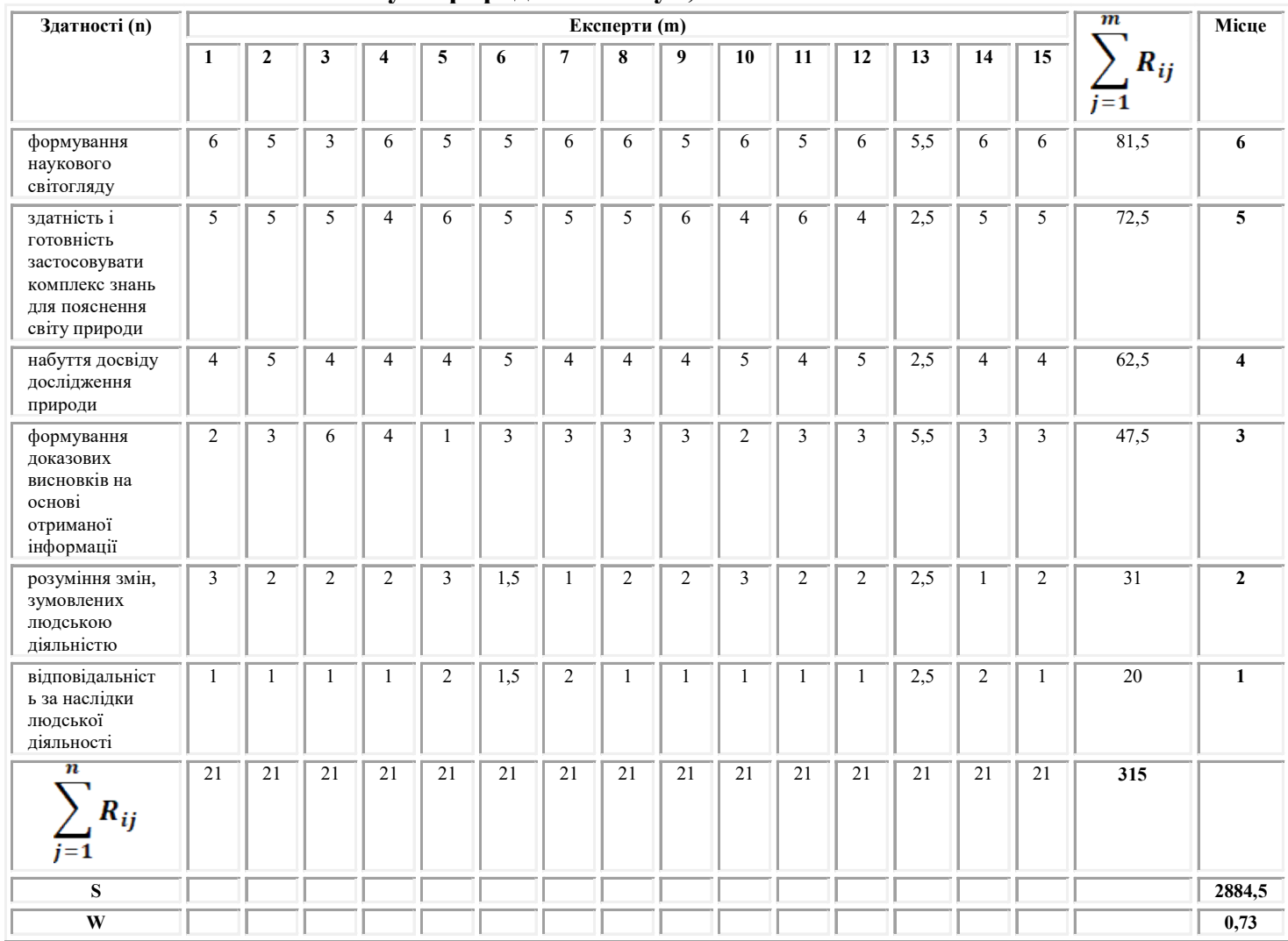


Таблиця 4.

Експертне оцінювання здібностей компетентності “інноваційність"

\begin{tabular}{|c|c|c|c|c|c|c|c|c|c|c|c|c|c|c|c|c|c|}
\hline \multirow[t]{2}{*}{ Здатності (n) } & \multicolumn{15}{|c|}{ Експерти (m) } & \multirow{2}{*}{$\sum_{i=1}^{m} R_{i j}$} & \multirow[t]{2}{*}{ Місце } \\
\hline & 1 & 2 & 3 & 4 & 5 & 6 & 7 & 8 & 9 & 10 & 11 & 12 & 13 & 14 & 15 & & \\
\hline $\begin{array}{l}\text { спроможність } \\
\text { визначати i } \\
\text { ставити перед } \\
\text { собою цілі, } \\
\text { мотивувати і } \\
\text { розвивати } \\
\text { себе }\end{array}$ & 1 & 1 & 1,5 & 1,5 & 2 & 1 & 1 & 3 & 1,5 & 2 & 1,5 & 1 & 2 & 2 & 2 & 24 & 1 \\
\hline $\begin{array}{l}\text { відкритість до } \\
\text { нових ідей }\end{array}$ & 2 & 2 & 3 & 3 & 1 & 2 & 2 & 1 & 3 & 1 & 1,5 & 2,5 & 1 & 1 & 1 & 27 & 2 \\
\hline $\begin{array}{l}\text { ініціювання } \\
\text { змін у групі, } \\
\text { закладі } \\
\text { освіти, } \\
\text { родині, } \\
\text { громаді }\end{array}$ & 4 & 3 & 4 & 4 & 3 & 4 & 4 & 4 & 4 & 4 & 4 & 4 & 4 & 4 & 4 & 58 & 4 \\
\hline $\begin{array}{l}\text { здатність } \\
\text { реагувати на } \\
\text { зміни та } \\
\text { долати } \\
\text { труднощі }\end{array}$ & 3 & 4 & 1,5 & 1,5 & 4 & 3 & 3 & 2 & 1,5 & 3 & 3 & 2,5 & 3 & 3 & 3 & 41 & 3 \\
\hline$\sum_{i=1}^{n} R_{i j}$ & 10 & 10 & 10 & 10 & 10 & 10 & 10 & 10 & 10 & 10 & 10 & 10 & 10 & 10 & 10 & 150 & \\
\hline $\mathbf{S}$ & & & & & & & & & & & & & & & & & 725 \\
\hline $\mathbf{W}$ & & & & & & & & & & & & & & & & & 0,64 \\
\hline
\end{tabular}

За результатами ранжування математичної компетентності (табл. 2) визначено затребуваною для кравців та закрійників “здатність застосовувати математичні знання та методи для розв'язання проблем у повсякденному житті.

$$
x_{\phi}^{2}=18,5>6 \text {, отже з імовірністю } 95 \%
$$
можемо стверджувати про невипадковість отримання такого значення коефіцієнта конкордації.
За результатами ранжування компетентності в галузі природничих наук, техніки i технологій (табл. 3) визначено затребуваною для кравців та закрійників “відповідальність за наслідки людської діяльності”.

$x_{\phi}^{2}=54,9>11,1$, отже з ймовірністю $95 \%$ можемо стверджувати про невипадковість отримання такого значення коефіцієнта конкордації.

За результатами ранжування компетентності

Таблиця 5.

Експертне оцінювання здібностей екологічної компетентності

\begin{tabular}{|c|c|c|c|c|c|c|c|c|c|c|c|c|c|c|c|c|c|}
\hline \multirow[t]{2}{*}{ Здатності (n) } & \multicolumn{15}{|c|}{ Експерти (m) } & \multirow{2}{*}{$\sum_{j=1}^{m} R_{i j}$} & \multirow[t]{2}{*}{ Місце } \\
\hline & 1 & 2 & 3 & 4 & 5 & 6 & 7 & 8 & 9 & 10 & 11 & 12 & 13 & 14 & 15 & & \\
\hline $\begin{array}{l}\text { розуміння важливості } \\
\text { збереження природи } \\
\text { для забезпечення } \\
\text { сталого розвитку } \\
\text { суспільства }\end{array}$ & 3 & 3 & 3 & 3 & 3 & 2,5 & 3 & 3 & 3 & 3 & 3 & 3 & 3 & 3 & 3 & 44,5 & 3 \\
\hline $\begin{array}{l}\text { усвідомлення } \\
\text { ощадливого } \\
\text { використання } \\
\text { природних ресурсів }\end{array}$ & 2 & 1,5 & 1 & 2 & 2 & 1 & 2 & 1 & 2 & 2 & 1,5 & 1 & 2 & 2 & 2 & 25 & 2 \\
\hline $\begin{array}{l}\text { усвідомлення } \\
\text { екологічних основ } \\
\text { природокористування }\end{array}$ & 1 & 1,5 & 2 & 1 & 1 & 2,5 & 1 & 2 & 1 & 1 & 1,5 & 2 & 1 & 1 & 1 & 20,5 & 1 \\
\hline$\sum_{j=1}^{n} R_{i j}$ & 6 & 6 & 6 & 6 & 6 & 6 & 6 & 6 & 6 & 6 & 6 & 6 & 6 & 6 & 6 & 90 & \\
\hline $\mathbf{S}$ & & & & & & & & & & & & & & & & & 325,5 \\
\hline $\mathbf{W}$ & & & & & & & & & & & & & & & & & 0,72 \\
\hline
\end{tabular}


Таблиця 6.

Експертне оцінювання здібностей інформаційно-комунікаційної компетентності

\begin{tabular}{|c|c|c|c|c|c|c|c|c|c|c|c|c|c|c|c|c|c|}
\hline \multirow[t]{2}{*}{ Здатності (n) } & \multicolumn{15}{|c|}{ Експерти (m) } & \multirow{2}{*}{$\sum_{j=1}^{m} R_{i j}$} & \multirow[t]{2}{*}{ Місце } \\
\hline & 1 & 2 & 3 & 4 & 5 & 6 & 7 & 8 & 9 & 10 & 11 & 12 & 13 & 14 & 15 & & \\
\hline $\begin{array}{l}\text { здатність до } \\
\text { впевненого, } \\
\text { критичного і } \\
\text { відповідального } \\
\text { використання } \\
\text { цифрових } \\
\text { технологій }\end{array}$ & 1 & 1,5 & 1 & 1,5 & 1 & 1 & 2 & 1 & 1 & 1 & 1 & 1 & 1 & 1 & 1 & 17 & 1 \\
\hline $\begin{array}{l}\text { здатність } \\
\text { безпечно } \\
\text { застосовувати } \\
\text { інформаційно- } \\
\text { комунікаційні } \\
\text { засоби }\end{array}$ & 2 & 1,5 & 2 & 1,5 & 2 & 2 & 1 & 2 & 2 & 2 & 2 & 2 & 2 & 2 & 2 & 28 & 2 \\
\hline$\sum_{i=1}^{n} R_{i j}$ & 3 & 3 & 3 & 3 & 3 & 3 & 3 & 3 & 3 & 3 & 3 & 3 & 3 & 3 & 3 & 45 & \\
\hline $\mathbf{S}$ & & & & & & & & & & & & & & & & & 60,5 \\
\hline $\mathbf{W}$ & & & & & & & & & & & & & & & & & 0,54 \\
\hline
\end{tabular}

Експертне оцінювання здібностей

Таблиця 7. компетентності “навчання впродовж життя"

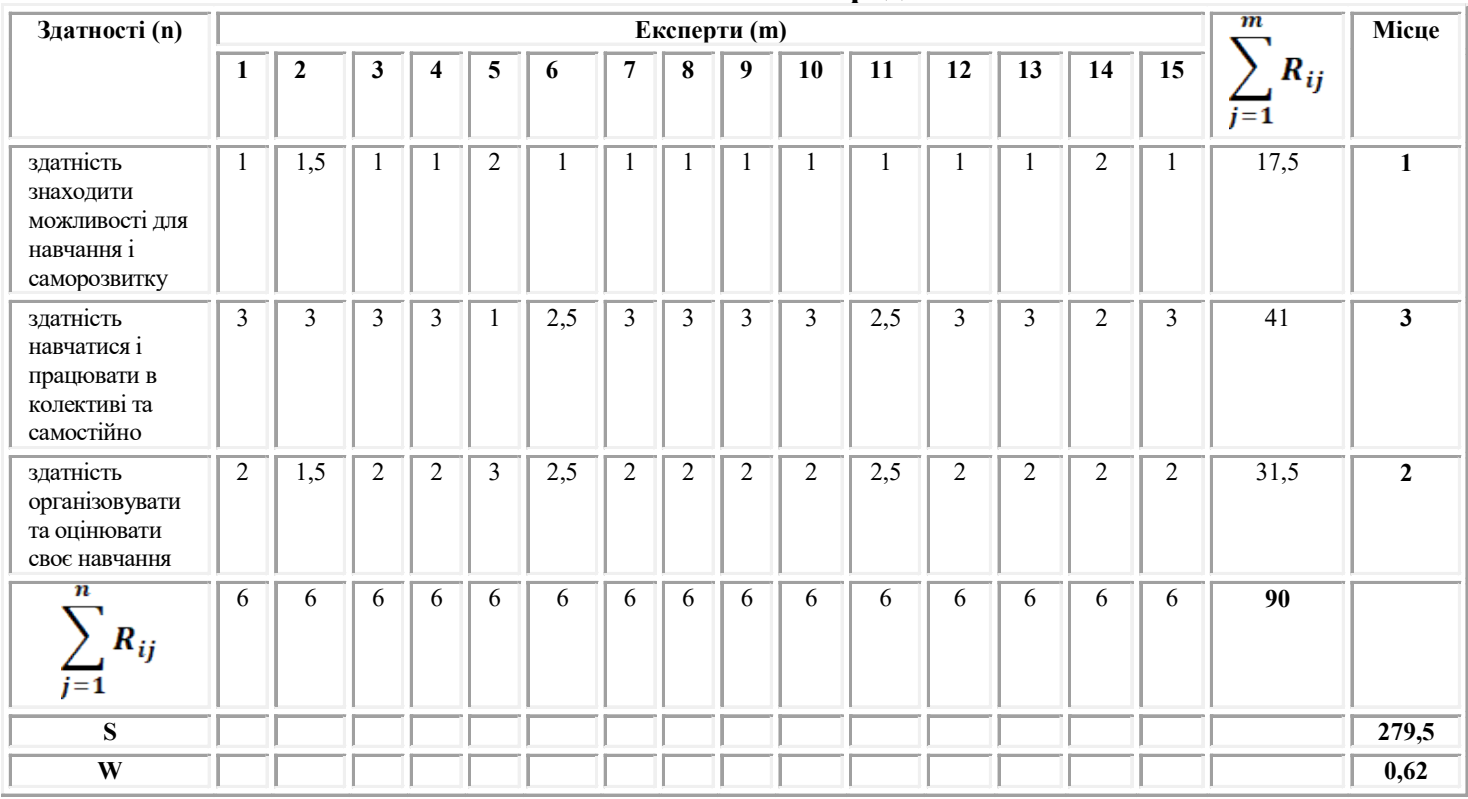

“інноваційність” (табл. 4) визначено затребуваною для кравців та закрійників “спроможність визначати $i$ ставити иілі, мотивувати себе".

$x_{\phi}^{2}=29>7,8$, отже з ймовірністю 95\% можемо стверджувати, що значення коефіцієнта конкордації є невипадковим.

За результатами ранжування екологічної компетентності (табл. 5) визначено значущим для кравців і закрійників “усвідомлення екологічних основ природокористування".

$x_{\phi}^{2}=21,7>6$, отже з ймовірністю $95 \%$ можемо стверджувати про невипадковість отримання такого значення коефіцієнта конкордації.

За результатами ранжування інформаційно- 
Експертне оцінювання здібностей

Таблиця 8. громадянської та соціальної компетентностей

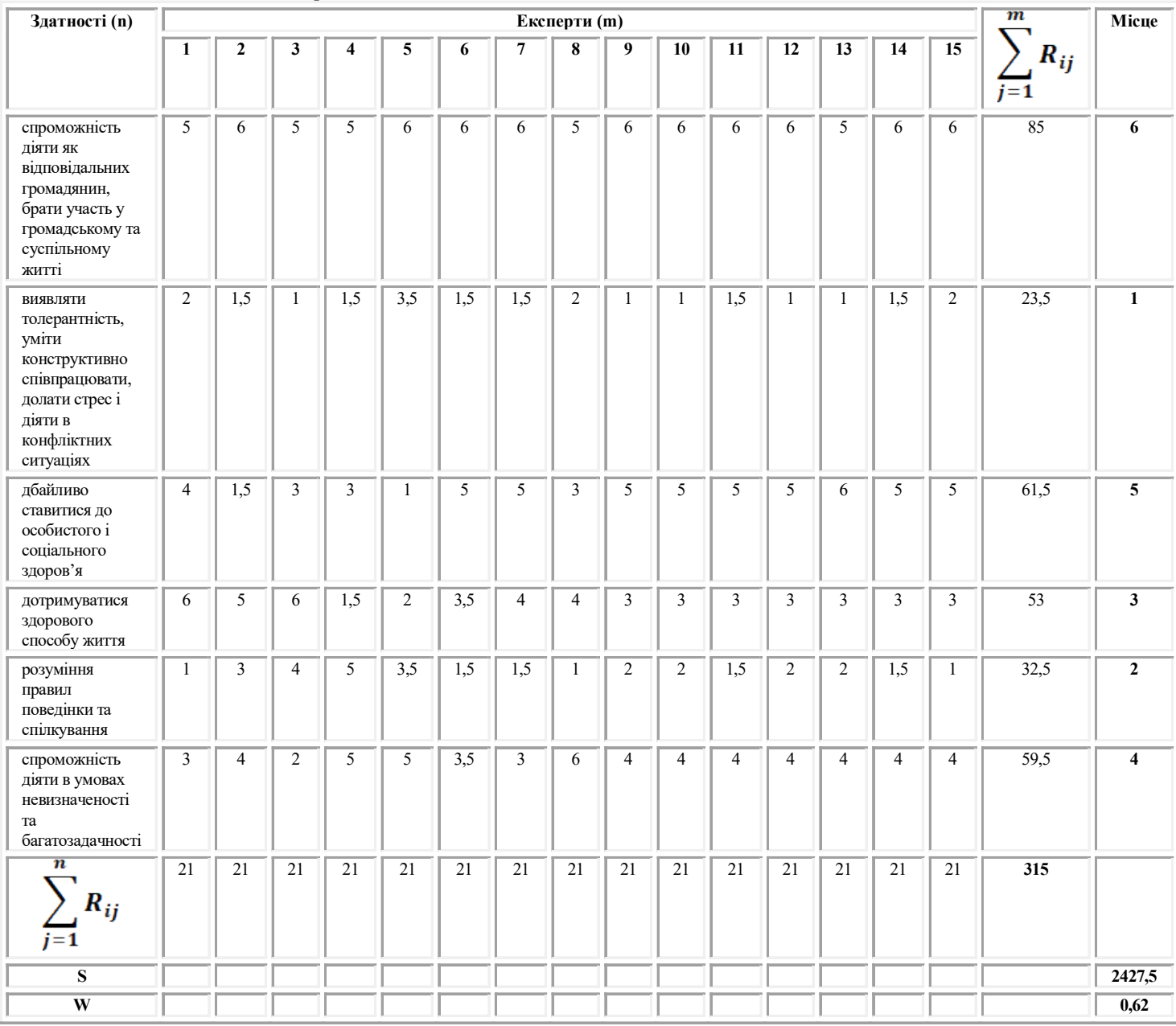

Таблиця 9.

\begin{tabular}{|c|c|c|c|c|c|c|c|c|c|c|c|c|c|c|c|c|c|}
\hline \multirow[t]{2}{*}{ 3датності (n) } & \multicolumn{15}{|c|}{ Експерти (m) } & \multirow{2}{*}{$\sum_{i=1}^{m} R_{i j}$} & \multirow[t]{2}{*}{ Місце } \\
\hline & 1 & 2 & 3 & 4 & 5 & 6 & 7 & 8 & 9 & 10 & 11 & 12 & 13 & 14 & 15 & & \\
\hline $\begin{array}{l}\text { наявність } \\
\text { стійкого } \\
\text { інтересу до } \\
\text { опанування } \\
\text { культурних і } \\
\text { мдстецьких } \\
\text { здобутків } \\
\text { України та світу }\end{array}$ & 3 & 4 & 2,5 & 4 & 4 & 4 & 4 & 4 & 4 & 4 & 3 & 4 & 4 & 4 & 4 & 56,5 & 4 \\
\hline $\begin{array}{l}\text { шанобливе } \\
\text { ставлення до } \\
\text { культурних } \\
\text { традицій } \\
\text { украйнців та } \\
\text { iнших держав та } \\
\text { народів }\end{array}$ & 4 & 3 & 4 & 1,5 & 3 & 1,5 & 2 & 3 & 3 & 3 & 1,5 & 3 & 1,5 & 3 & 3 & 40 & 3 \\
\hline $\begin{array}{l}\text { здатність } \\
\text { розуміти і } \\
\text { цінувати творчі } \\
\text { способи } \\
\text { вираження та } \\
\text { передачі ідей у } \\
\text { різихх } \\
\text { культурах }\end{array}$ & 2 & 1,5 & 2,5 & 3 & 1,5 & 3 & 3 & 2 & 2 & 2 & 4 & 2 & 3 & 2 & 2 & 35,5 & 2 \\
\hline
\end{tabular}




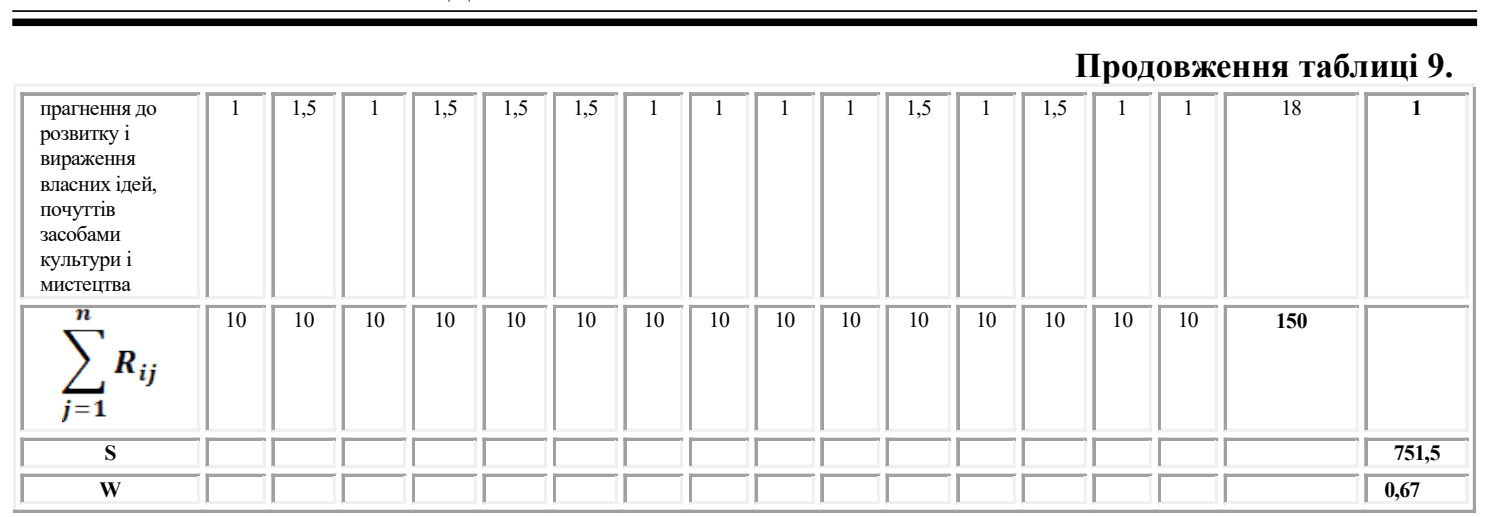

комунікаційної компетентності (табл. 6) визначено найбільш важливою "здатність до впевненого, критичного і відповідального використання циифрових технологій”.

$$
x_{\phi}^{2}=8,1>3,8 \text {, отже з ймовірністю } 95 \%
$$

можемо говорити про невипадковість отримання такого значення коефіцієнта конкордації.

За результатами ранжування компетентності “навчання впродовж життя" (табл. 7) визначена як необхідна для кравців і закрійників “здатність знаходити можливість для навчання $i$ саморозвитку”.

$x_{\phi}^{2}=18,6>6$, отже з імовірністю в $95 \%$ можна констатувати невипадковість отримання такого значення коефіцієнта конкордації.

За результатами ранжування громадянської і соціальної компетентностей (табл. 8) для кравців та закрійників найбільш актуальним визначено уміння “виявляти толерантність, уміти конструктивно співпрацювати, долати стрес і діяти в конфліктних ситуаціях".

$x_{\phi}^{2}=46,2>11,1$, тобто $95 \%$ імовірності свідчать про невипадковість отримання такого значення коефіцієнта конкордації.

За результатами ранжування культурної компетентності (табл. 9) визначено найбільш затребуваним “"ррагнення до розвитку $i$ вираження власних ідей $і$ почуттів засобами культури й мистещтва".

$x_{\phi}^{2}=30,1>7,8$, що з імовірністю $95 \%$ дає змогу говорити про невипадковість отримання даного значення коефіцієнта конкордації.

За результатами ранжування компетентності “підприємливість і фінансова грамотність" (табл. 10) визначено здібності, найбільш затребувані для кравців та закрійників “здатність до керування власним життям та кар 'єрою” та “здатність працювати в команді для планування і реалізації проєктів". Дані здібності отримали однакову суму рангів - 30,5, тому по мірі своєї затребуваності посідають у рангу два перших місця.

$$
x_{\phi}^{2}=46>11,1 \text {, що з імовірністю 95\% }
$$

свідчить про невипадковість отримання такого значення коефіцієнта конкордації.

Отримані дані дають змогу конкретизувати суть поняття “ключові компетентності майбутніх кваліфікованих робітників швейного профілю”, визначаючи його як інтегроване утворення, спеціально структурований професійно орієнтований комплекс якостей i здібностей кравців і закрійників, необхідний для досягнення ними професійного успіху, підвищення конкурентоспроможності, формування професійної мобільності й адаптації на ринку праці, що включає: здатність здійснювати комунікацію в усній та письмовій формах (мовна компетентність); здатність застосовувати математичні знання та методи для розв'язування проблем у повсякденному житті (математична компетентність); відповідальність за наслідки людської діяльності (компетентність у галузі природничих наук), спроможність визначати i ставити перед собою цілі, мотивувати себе і розвивати (інноваційність), усвідомлення екологічних основ природокористування (екологічна компетентність), здатність до впевненого, критичного і відповідального використання цифрових технологій (інформаційнокомунікаційна компетентність), здатність знаходити можливості для навчання й саморозвитку (навчання впродовж життя), здатність виявляти толерантність, уміти конструктивно співпрацювати, долати стрес і діяти в конфліктних ситуаціях (громадянські та соціальні компетентності), прагнення до розвитку й вираження власних ідей і почуттів засобами культури й мистецтва (культурна компетентність); здатність керувати власним життям і кар'єрою, здатність працювати в команді для планування й 
Експертне оцінювання здібностей компетентності "підприємливість і фінансова грамотність"

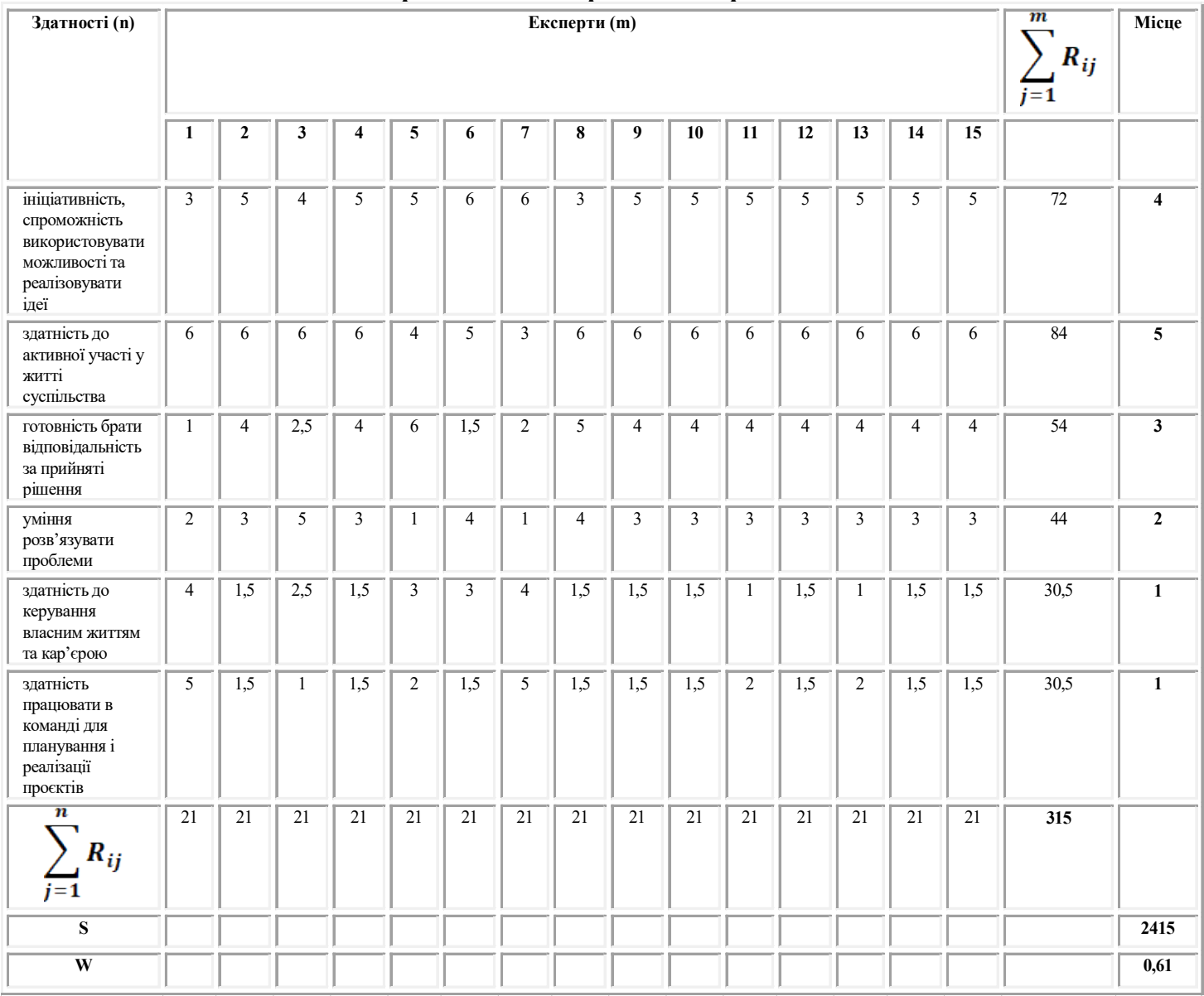

реалізації проєктів (підприємливість і фінансова грамотність). Формування у фахівців швейної галузі даних якостей і здібностей, як найбільш затребуваних сучасним ринком праці складових ключових компетентностей, сприятиме досягненню кравцями i закрійниками професійного успіху, особистісній реалізації, забезпеченню професійної мобільності та ефективної міжособистісної взаємодії в умовах швейного виробництва, формуванню адаптивності на ринку праці.

Висновки і перспективи подальших розвідок. Експертне оцінювання ключових компетентностей дало можливість обрати найбільш затребувані здібності для професій “Кравець” i “Закрійник”, які в подальшому будуть формуватися завдяки цілеспрямованому використанню спеціально підібраних інтерактивних технологій навчання. Результати даного дослідження можна враховувати при формуванні переліку ключових компетентностей для професій швейного профілю під час розробки/ оновлення стандартів професійної (професійнотехнічної) освіти за компетентнісним підходом та професійних стандартів. Важливим напрямом подальших досліджень $є$ висвітлення експериментальної перевірки розвитку висвітлених ключових компетентностей засобами інтерактивних технологій в процесі професійної підготовки кваліфікованих робітників швейного профілю.

\section{ЛІТЕРАТУРА}

1. Грабовецький Б. С. Методи експертних оцінок: теорія, методологія, напрямки використання. Вінниця, 2010. 171 с.

2. Державний стандарт професійно-технічної освіти “Закрійник” (2016). URL: https://mon.gov.ua/ ua/osvita/profesijno-tehnichna-osvita/derzhavnistandarti-navchalni-plani-ta-programi/zatverdzhenistandarti-profesijno-tehnichnoyi-osviti-2006-2016 (дата звернення: 15.04.2021).

3. Державний стандарт професійно-технічної освіти “Кравець” (2016). URL: https://mon.gov.ua/ 


\section{ЕКСПЕРТНЕ ОЩНЮВАННЯ КЛЮЧОВИХКОМПЕТЕНТНОСТЕЙ ДЛЯ ПРОФЕСІЙ ШВЕЙНОГОПРОФІЛЮ}

ua/osvita/profesijno-tehnichna-osvita/derzhavnistandarti-navchalni-plani-ta-programi/zatverdzhenistandarti-profesijno-tehnichnoyi-osviti-2006-2016 (дата звернення: 15.04.2021).

4. Державний стандарт професійно-технічної освіти “Швачка" (2016). URL: https://mon.gov.ua/ ua/osvita/profesijno-tehnichna-osvita/derzhavnistandarti-navchalni-plani-ta-programi/zatverdzhenistandarti-profesijno-tehnichnoyi-osviti-2006-2016 (дата звернення: 15.04.2021).

5. Концепція реалізації державної політики у сфер професійної (професійно-технічної) освіти “Сучасна професійна (професійно-технічна) освіта” на період до 2027 року. (2019). URL: https:/ /zakon.rada.gov.ua/laws/show/419-2019\%D1\%80\#Text (дата звернення: 15.04.2021).

6. Кравець С. Трансформація ключових компетентностей майбутніх фахівців готельноресторанного сервісу в умовах інтернаціоналізації. Молодь і ринок. 2018. № 1 (156). С. 61-66.

7. Методика розроблення професійних стандартів. (2018) URL: https://zakon.rada.gov.ua/ laws/show/z0165-18\#Text (дата звернення: 04.05.2021).

8. Наказ "Про затвердження методичних рекомендацій щодо розроблення стандартів професійної (професійно-технічної) освіти за компетентнісним підходом". (2021). URL: https:// mon.gov.ua/ua/npa/pro-zatverdzhennya-metodichnihrekomendacij-shodo-rozroblennya-standartivprofesijnoyi-profesijno-tehnichnoyi-osviti-zakompetentnishim-pidhodom (дата звернення: 20.04.2021).

9. Осипов Г. В. Рабочая книга социолога. Москва, 2006. 480 с.

10.Ярощук Л. Д. Інтелектуальні системи управління. Київ, 2017. 40 с.

\section{REFERENCES}

1. Hrabovetsky, B. Ye. (2010). Metody ekspertnykh otsinok: teoriya, metodolohiya, napryamky vykorystannya [Methods of expert assessments: theory, methodology, areas of use]. Vinnitsa, 171 p. [in Ukrainian].

2. Derzhavnyy standart profesiyno-tekhnichnoyi osvity "Kravets" (2016). [State standard of vocational education "Tailor"]. Available at: https://mon.gov.ua/ ua/osvita/profesijno-tehnichna-osvita/derzhavnistandarti-navchalni-plani-ta-programi/zatverdzhenistandarti-profesijno-tehnichnoyi-osviti-2006-2016 (Accessed 15 Apr 2021) [in Ukrainian].

3. Derzhavnyy standart profesiyno-tekhnichnoyi osvity "Zakriynyk" (2016). [State standard of vocational education "Cutter"]. Available at: https:// mon.gov.ua/ua/osvita/profesijno-tehnichna-osvita/ derzhavni-standarti-navchalni-plani-ta-programi/ zatverdzheni-standarti-profesijno-tehnichnoyi-osviti2006-2016 (Accessed 15 Apr 2021) [in Ukrainian].

4. Derzhavnyy standart profesiyno-tekhnichnoyi osvity "shvachka" (2016). [State standard of vocational education "Seamstress"]. Available at: https://mon.gov.ua/ua/osvita/profesijno-tehnichnaosvita/derzhavni-standarti-navchalni-plani-taprogrami/zatverdzheni-standarti-profesijnotehnichnoyi-osviti-2006-2016 (Accessed 15 Apr 2021) [in Ukrainian].

5. Kontseptsiya realizatsiyi derzhavnoyi polityky u sfer profesiynoyi (profesiyno-tekhnichnoyi) osvity "Suchasna profesiyna (profesiyno-tekhnichna) osvita" na period do 2027 roku (2019). [The concept of implementation of state policy in the field of vocational (vocational) education "Modern vocational (vocational) education" for the period up to 2027]. Available at: https://zakon.rada.gov.ua/laws/show/ 419-2019-\%D1\%80\#Text (Accessed 15 Apr 2021) [in Ukrainian].

6. Kravets, S. (2018). Transformatsiya klyuchovykh kompetentnostey maybutnikh fakhivtsiv hotelno-restorannoho servisu $\mathrm{v}$ umovakh internatsionalizatsiyi [Transformation of key competencies of future specialists of hotel and restaurant service in the conditions of internationalization]. Youth \& market. No. 1 (156). pp. 61-66. [in Ukrainian].

7. Metodyka rozroblennya profesiynykh standartiv (2018). [Methods of developing professional standards.]. Available at: https:// zakon.rada.gov.ua/laws/show/z0165-18\#Text (Accessed 04 May 2021) [in Ukrainian].

8. Nakaz "Pro zatverdzhennya metodychnykh rekomendatsiy shchodo rozroblennya standartiv profesiynoyi (profesiyno-tekhnichnoyi) osvity za kompetentnisnym pidkhodom" (2021). [Order "On approval of methodological recommendations for the development of standards of professional (vocational) education according to the competence approach"]. Available at: https://mon.gov.ua/ua/npa/prozatverdzhennya-metodichnih-rekomendacij-shodorozroblennya-standartiv-profesijnoyi-profesijnotehnichnoyi-osviti-za-kompetentnishim-pidhodom (Accessed 20 Apr 2021) [in Ukrainian].

9. Osipov, G. V. (2006). Rabochaya kniga sotsiologa [Working book of a sociologist]. Moscow, 480 p. [in Russian].

10. Yaroshchuk, L. D. (2017). Intelektualni systemy upravlinnya [Intelligent control systems]. Kyiv, 40 p. [in Ukrainian].

Стаття надійшла до редакції 29.07.2021 